\title{
Evolution of a traditional technique: Comparison of a 4-mm lag screw and Kirschner wire technique versus a 4-mm lag screw and Kirschner technique with anti-gliding miniplate fixation for the treatment of medial malleolar fractures
}

\author{
(1) Murat Aydın, M.D.,' (1) Selim Çınaroğlu, M.D. ${ }^{2}$
}

\begin{abstract}
1Department of Orthopedics and Traumatolgy, Niğde Ömer Halisdemir University Faculty of Medicine, Niğde-Turkey
${ }^{2}$ Department of Anatomy, Niğde Ömer Halisdemir University Faculty of Medicine, Niğde-Turkey
\end{abstract}

\begin{abstract}
BACKGROUND: In this study, we aimed to compare a 4-mm lag screw and Kirschner wire technique versus a 4-mm lag screw and Kirschner wire (K-wire) technique with additional miniplate fixation for the treatment of medial malleolar fractures.

METHODS: A total of 23 patients who were diagnosed with isolated fractures of the medial malleolus and operated in our center were retrospectively analyzed. The patients were divided into two groups: Group A, medial malleolar fracture fixed with a 4-mm cannulated screw and a K-wire $(n=I I)$ and Group B, a 4-mm cannulated screw and K-wire used for fixation with miniplate fixation for extra stability $(n=12)$. Clinical outcomes were assessed using the American Orthopaedic Foot and Ankle Society (AOFAS) Ankle-Hindfoot Score at 2, 6, 12, and 24 months postoperatively. At 12-24 months, the presence of pain and tenderness in the medial malleolus with palpation was evaluated using the visual analog scale (VAS) pain scores.

RESULTS: The mean time to union was $2.23 \pm 0.56$ (range, 1.8-2.9) months in Group A and 2.46 \pm 0.45 (range, 1.9-3.I) months in Group B, indicating no statistically significant difference between the two groups ( $>00.05$ ). The mean AOFAS score at 2 months postoperatively was $60.40 \pm 7.78$ (range, 46-79) in Group A and 73.60 10.80 (range, 53-87) in Group B, indicating a statistically significant difference between the groups $(p<0.01)$. However, there was no statistically significant difference in the mean AOFAS scores at 6 and 12 months between the groups ( $p>0.05$ ). The mean VAS pain scores at $12-24$ months postoperatively did not significantly differ between the groups $(p>0.05)$.
\end{abstract}

CONCLUSION: Our study results suggest that the treatment of medial malleolar fractures with a cannulated screw and K-wire with additional stabilization using a miniplate ensures favorable early outcomes with early return to daily living activities. However, both techniques have similar outcomes in the mid-term.

Keywords: Kirschner wire; medial malleolus fractures; mini-plate; open reduction internal fixation; trauma.

\section{INTRODUCTION}

Non-displaced medial malleolar fractures are relatively rare fractures of the ankle and are usually treated with cast immobilization; however, displaced fractures should be treated with open reduction and internal fixation. Treating displaced isolated medial malleolar fractures with conservative treatment methods result in high rates of non-union and poor functional outcomes, and a varus tilt may develop in case of nonunion and displacement. ${ }^{[1]}$ Accumulated clinical experience has led to the development of a treatment option involving the anatomical reduction of the ankle in ankle fractures. ${ }^{[2,3]}$ Displaced unimalleolar fractures are high-energy fractures and have been associated with good clinical outcomes with good

\footnotetext{
Cite this article as: Aydın M, Çınaroğlu S. Evolution of a traditional technique: Comparison of a 4-mm lag screw and Kirschner wire technique versus a 4-mm lag screw and Kirschner technique with anti-gliding miniplate fixation for the treatment of medial malleolar fractures. Ulus Travma Acil Cerrahi Derg 2022;28:336-343.
}

Address for correspondence: Murat Aydın, M.D.

Niğde Ömer Halisdemir Üniversitesi Tıp Fakültesi, Ortopedi ve Travmatoloji Anabilim Dalı, Niğde, Turkey

Tel: +90388 - 2256050 E-mail: opr.murataydin@gmail.com

Ulus Travma Acil Cerrahi Derg 2022;28(3):336-343 DOI: 10.14744/tjtes.202I.49734 Submitted: 07.07.202I Accepted: I5.I0.202I

Copyright 2022 Turkish Association of Trauma and Emergency Surgery 
anatomic reduction and internal fixation. However, there is still a lack of consensus on the optimal treatment of isolated medial malleolar fractures, despite the availability of advanced surgical techniques.

The currently available fixation techniques for medial malleolar fractures include a single-lag screw for small fragment fractures; a 4-mm cannulated cancellous lag screw and a Kirschner wire (K-wire) for displaced large transverse fractures; a tension band wire (TBW) for low transverse fractures; and a vertical countersunk 4-mm lag screw for low transverse fractures or plate fixation for high horizontal fractures. ${ }^{[4]}$

Medial malleolar injuries are ultimately intra-articular fractures characterized by high rates of non-union, delayed union, and delayed return to daily living activities, as well as early post-traumatic arthritis, if not treated surgically. Following open reduction and internal fixation, it is of utmost importance to initiate early joint motion exercises, although stable fracture fixation is required before the initiation of early motion in intra-articular fractures.

In the present study, we aimed to evaluate the cannulated cancellous screw, K-wire fixation, and miniplate-screw combination for the surgical treatment of isolated displaced medial malleolar fractures. We also aimed to follow the improvement in early joint motion and ankle clinical scores to develop a more stable approach to the treatment of such fractures.

\section{MATERIALS AND METHODS}

This retrospective study was conducted at Niğde Ömer Halisdemir University, Department of Orthopedics and Traumatology between January I, 2012 and September I, 2020. The study protocol was approved by the Institutional Review Board of the Niğde Ömer Halisdemir University Faculty of Medicine (No: 2020/67). A written consent was obtained from each patient. The study was conducted in accordance with the principles of the Declaration of Helsinki.

A total of 39 patients who were diagnosed with isolated fractures of the medial malleolus in our clinic and operated were included in the study. All patients were operated by a single surgeon. Exclusion criteria were as follows: The presence of open growth plates $(n=3)$, open fractures $(n=4)$, subluxation of the talus ( $n=3)$, an accompanying tibial shaft fracture $(n=4)$, and infection (sepsis and malignancy for another reason, $n=1$ ). During follow-up, one patient died from another medical condition (malignancy). Finally, a total of 23 patients who fulfilled the inclusion criteria were enrolled.

The patients were divided into two groups: Group A, medial malleolar fracture fixed with a 4-mm cannulated cancellous screw and a K-wire ( $\mathrm{n}=\mathrm{I}$ I) (Fig. I) and Group B, a 4-mm cannulated cancellous screw and $\mathrm{K}$-wire used for fixation with miniplate fixation for extra stability $(n=12)$ (Figs. 2 and 3).
The classifications of Müller et al. ${ }^{[3]}$ and Pankovich and Shivaram ${ }^{[5]}$ were modified to group the fractures into four simple patterns. Type A fractures were avulsions to the tip of the malleolus; Type $B$ fractures were located between the tip and the level of the plafond; Type $C$ fractures were at the level of the plafond; and Type $D$ fractures extended vertically above this level. There were seven patients with Type B, 10 patients with Type $C$, and six patients with Type $D$ fractures. The fracture was diagnosed by direct radiography and additional fractures were investigated with computed tomography, if indicated (Fig. I).

Radiological assessments were made using anteroposterior (AP), lateral, and mortise radiographs, and focused on bony callus tissue bridging (Fig. I). Non-union was defined as the absence of bony callus tissue in direct radiographs for 4 months. All radiological assessments (bone union and classifications) were made by a single-experienced radiologist. All operations, clinical assessments, diagnoses, surgical indications, follow-up, and scoring were performed by a single orthopedic surgeon.

The amount of pre-operative displacement was decided on based on AP radiographs, and surgery was planned. The displacement amounts measured from direct radiographs ranged from 2 to $7 \mathrm{~mm}$.

Clinical outcomes were assessed based on the American Orthopedic Foot and Ankle Society (AOFAS) Ankle-Hindfoot Score. Using the 100-point AOFAS scoring system, a score of $\geq 90$ points is considered excellent, 80-89 points as good, 70-79 points as fair, and $\leq 69$ points as poor. ${ }^{[6]}$ The scores were recorded at 2, 6, 12, and 24 months postoperatively. At 12-24 months, the presence of pain and tenderness in the medial malleolus with palpation was evaluated and recorded based on the patient-reported, $10-\mathrm{cm}$ visual analog scale (VAS), in which zero indicates no pain and ten indicates severe pain. After showing the $10-\mathrm{cm}$ scale to the respondent, the patients were asked to rate the amount of pain experienced on palpation.

\section{Surgical Technique}

Under regional or general anesthesia, a leg tourniquet was applied with the patient in the supine position, and after appropriate staining and draping; an approximately $3-\mathrm{cm}$ incision was made through the tip of the medial malleolus. The skin and subcutaneous layers were passed and the fracture line was reached. The fracture ends were cleaned and temporary fixation was achieved with a reduction clamp. A 2.0 $\mathrm{K}$-wire and a cannulated cancellous screw were fixated to and compressed at the tip of the medial malleolus, as confirmed by fluoroscopy (Group A). In Group B, a 2-mm branched miniplate (X-or $Y$-type according to the anatomical position of the fracture) $\left(\mathrm{BNL}^{\circledR}\right)$ was bent using pliers into a form suitable for the fracture anatomy and type, fitting the contour of 

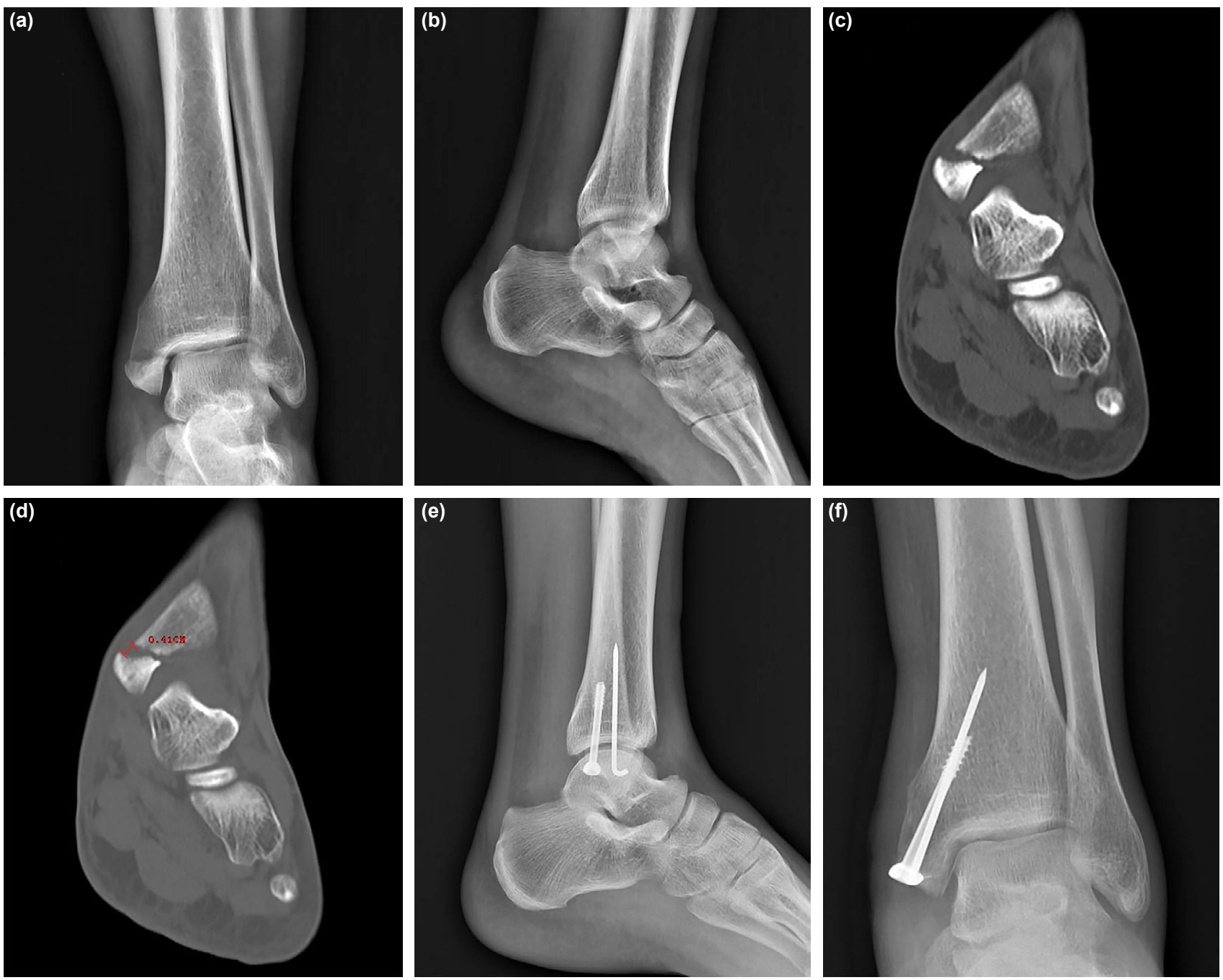

Figure 1. (a, b) Anteroposterior and lateral X-ray views in a 42-year-old male patient with isolated medial malleolus fracture after trauma. (c, d) The view of oblique displaced fracture line appearing hypointense in T1-weighted and hyperintense in T2-weighted sequences, (the displacement was measured as $4.1 \mathrm{~mm}$ on CT scans). (e, f) Medial malleolus fracture fixed with cancellous screw and a $\mathrm{K}$-wire at 24 months postoperatively (Group A).

the cortex to provide extra stability. Additional fixation was achieved with 2-mm miniscrews $\left(B N L^{\circledR}\right)$ applied distal and proximal to the fracture on the medial malleolus, with two screws on each side (Figs. 2 and 3). The surgical steps to the application of the miniscrews to the miniplate are as follows:

Step I: The surgeon should envisage the direction along which the K-wire and cannulated cancellous screw would advance in the tibia, and should drill for the miniscrew in the directions different from the advancing direction of the Kwire and cannulated cancellous screw. In our experience, no important issue can be expected proximal to the fracture, although particular care should be taken distal to the fracture while applying miniscrews. Otherwise, the screws may extend intra-articularly in the part of distal fracture.

Step 2: While opening a hole using a $1.2-\mathrm{mm}$ drill for the mini-screw, drilling should be advanced very gently and, if a metal-metal friction sound is heard (during drilling), drilling should be, then, made through another screw hole or in a different direction through the same screw hole. In cases where this is not possible, a shorter screw may be inserted through the same screw hole. To illustrate, if a metal-metal friction sound is heard during drilling, a 10-mm screw should be used following drilling a I4-mm hole (Figs. 4 and 5).

A short leg splint was fitted to all patients for 3 weeks at the end of the operation and surgical sutures were removed on post-operative day 15. Early passive exercises were initiated at 3 weeks, and physical therapy and rehabilitation were initiated at 4 weeks. The patients were mobilized with partial weight-bearing at 5 weeks, and full weight-bearing was initiated at 7-8 weeks, depending on fracture union as assessed by direct radiographs.

In Group A, one patient developed subacute superficial skin 

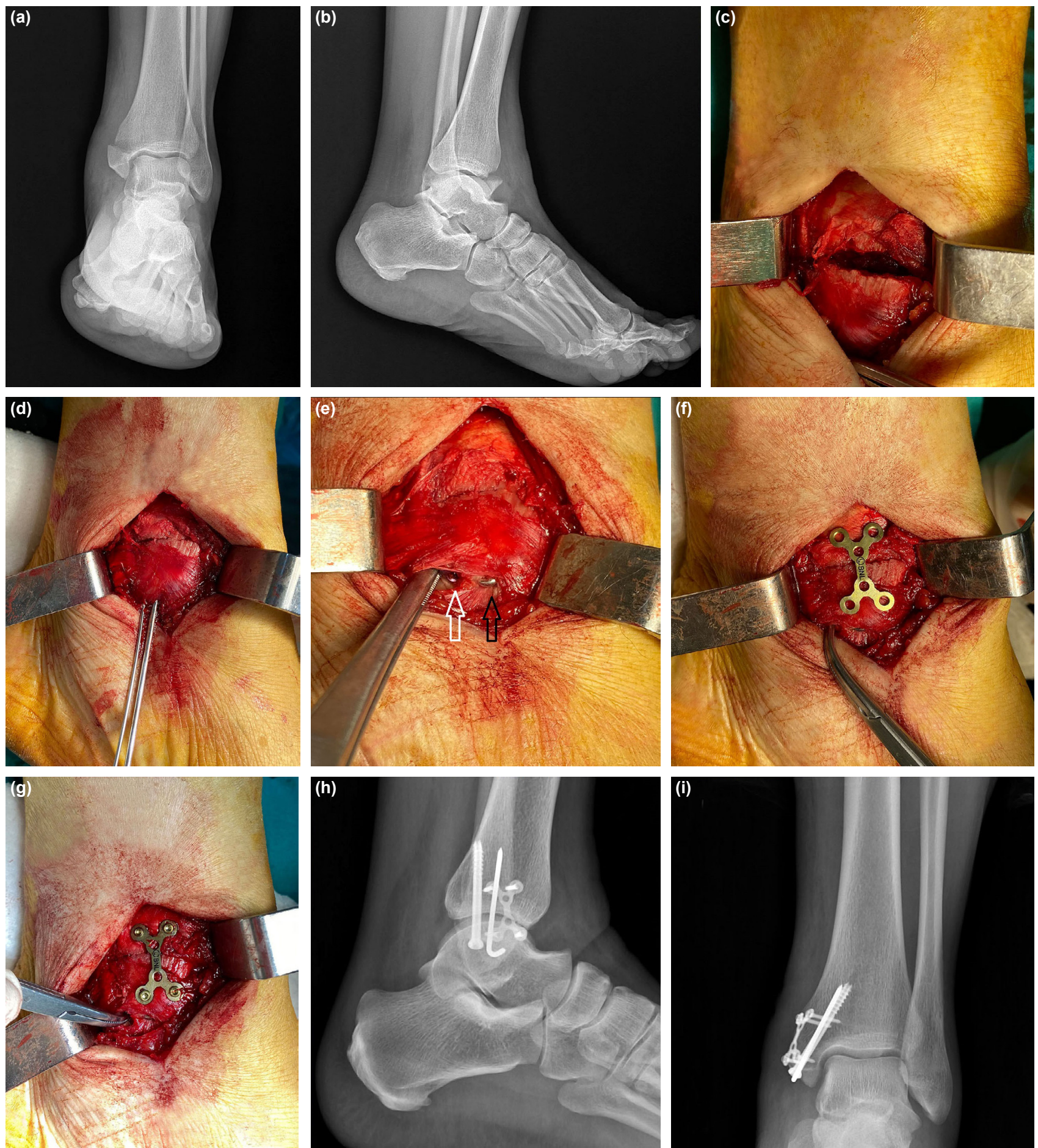

Figure 2. (a, b) Anteroposterior and lateral X-ray views in a 51-year-old male patient with isolated medial malleolus fracture after trauma. (c) Fracture line in the medial malleolus when visualized in medial direction. (d) Medial malleolus fracture fixed with two K-wires. (e) Medial malleolus fracture, black arrow pointing the cancellous screw, and white arrow pointing the K-wire. (f, g) Following the fixation of the fracture, mini-, and X-shaped plate was placed on the fracture with appropriate curves and contours. (h, i) The appearance at post-operative 2 years of medial malleolus fracture fixed with a miniplate in addition to fixation with a cancellous screw and a K-wire (Group B).

infection on post-operative day 10 and was treated with oral antibiotherapy. In Group B, one patient was re-operated after sustaining a segmental tibia shaft fracture during a fall at the post-operative $3^{\text {rd }}$ month, and was subsequently excluded from the study (tibia intramedullary nailing + plating for fibula fracture). In addition, two patients in Group A and one patient in Group B developed Sudeck's atrophy at 8-10 postoperative weeks and were treated with aggressive physical therapy. No non-union or implant failure was observed in any of the patients. 

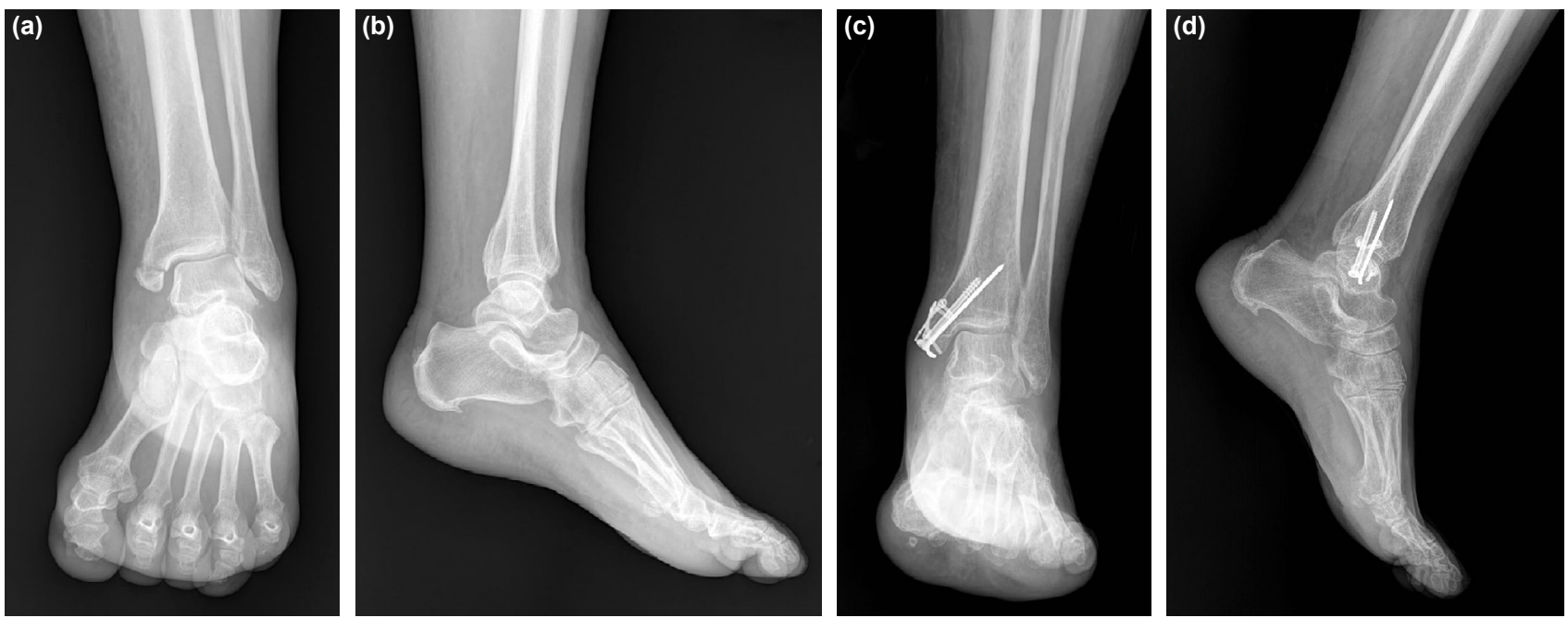

Figure 3. Anteroposterior and lateral X-ray views in a 42-year-old female patient with isolated medial malleolus fracture after trauma (a, b) pre-operative medial malleolar fracture, (b) appearance of union at 24 months postoperatively after fixation with a cannulated cancellous screw + K-wire + X shaped miniplate (Group B).

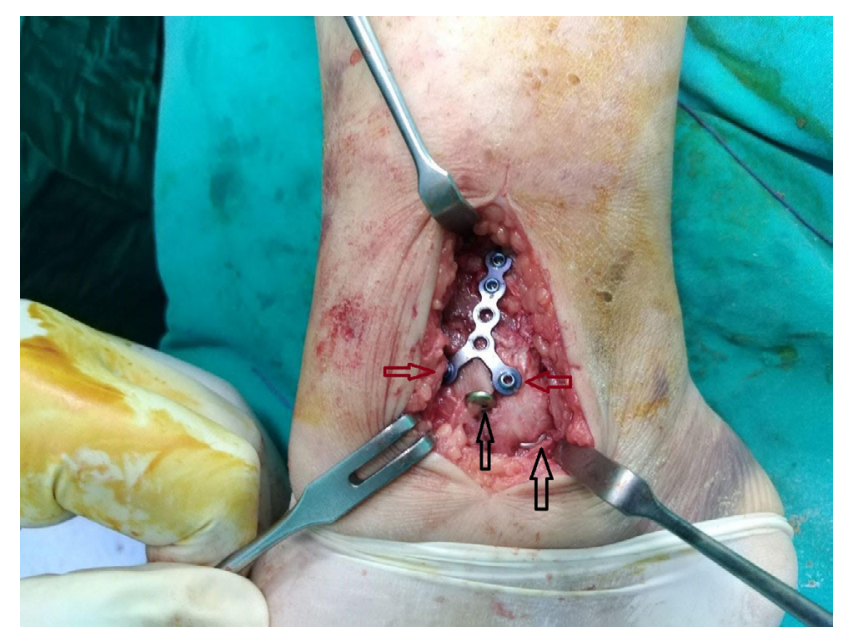

Figure 4. A 48-year-old male patient; intraoperative view of a medial malleolar fracture fixed with a cannulated cancellous screw and K-wire additional Y-shaped anti-gliding miniplate, Black arrow - Medial malleolar fracture fixed and compressed with a cannulated cancellous screw and K-wire, Red arrow - Miniscrew and plate applied in different directions according to the direction in the tibia of a cannulated cancellous screw and K-wire distal to the fracture (Group B).

\section{Statistical Analysis}

Statistical analysis was performed using the SPSS version 25.0 software (IBM Corp., Armonk, NY, USA). The study power $(I-\beta)$ was calculated as $0.78-0.80$ with $95 \%$ confidence interval and $\alpha=0.05$. Descriptive data were expressed in mean \pmstandard deviation, median (min-max), or number and frequency, where applicable. $\mathrm{P}<0.05$ was considered statistically significant.

\section{RESULTS}

Demographic and clinical characteristics of the patients are summarized in Table I. There were II patients in Group A and 12 patients in Group B. Of the patients, 14 were males

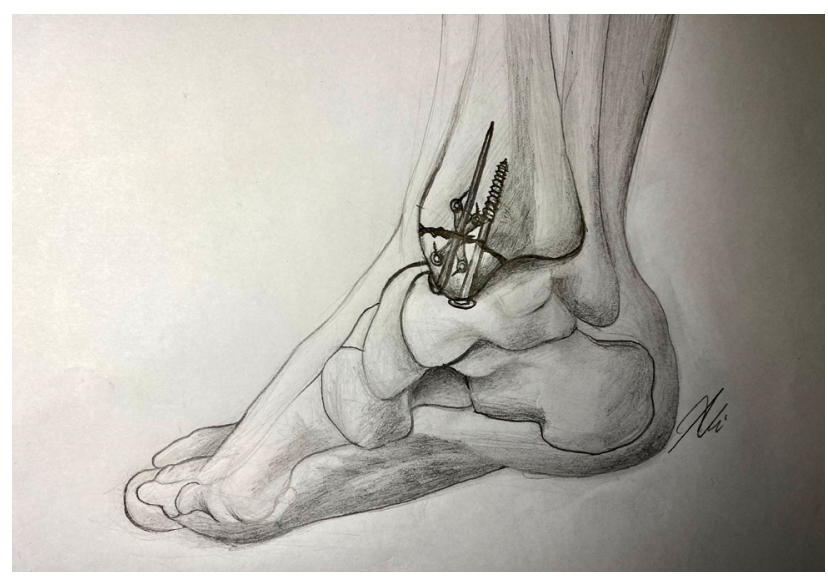

Figure 5. A drawing illustrating posteromedial view of medial malleolus fracture fixed with a miniplate in addition to fixation with a cancellous screw and a K-wire.

and nine were females. The mean age was 38.6 14.9 (range, $21-55$ ) years in Group A and $40.25 \pm 7.06$ (range, 20-59) years in Group B, indicating no statistically significant difference between the groups $(p>0.05)$.

There were no accompanying syndesmosis injuries or additional fractures in either group. The etiologies of the fractures included motorcycle accidents, falls, and sports injuries. The mean duration of follow-up was 31.45 \pm 8.16 (range, 28-44) months in Group A and 26.5 \pm 4.45 (range, 25-29) months in Group B. Surgical implants were removed at 12 months postoperatively in three patients in Group A and in four patients in Group B. All patients underwent anatomical reduction after surgery. None of the patients experienced non-union, loss of reduction, or implant failure during follow-up. Radiologically, the mean time to union was $2.23 \pm 0.56$ (range, 1.8-2.9) months in Group A and 2.46 \pm 0.45 (range, I.9-3.1) months in Group B, indicating no statistically significant difference between the two groups $(p>0.05)$. 
Table I. Demographic and clinical characteristics of the patients

\begin{tabular}{|c|c|c|c|}
\hline & $\begin{array}{l}\text { Group A } \\
\text { Treated by lag screw and } \\
\text { Kirschner wire technique }\end{array}$ & $\begin{array}{l}\text { Group B } \\
\text { Treated by 4-mm lag screw } \\
\text { technique and Kirschner technique } \\
\text { wire plus miniplate fixation }\end{array}$ & p-value \\
\hline $\mathrm{N}$ & 11 & 12 & \\
\hline \multicolumn{4}{|l|}{ Sex, n (\%) } \\
\hline Male & $7(63.6)$ & $7(58.3)$ & \\
\hline Female & $4(36.4)$ & $5(4 I .6)$ & \\
\hline Mean Age $\pm S D$ & $38.6 \pm \mid 4.9(2 \mid-55)$ & $40.25 \pm 7.06(20-59)$ & $.487^{¥}$ \\
\hline \multirow[t]{3}{*}{ Classification (Muller) } & Type B; 3 patients & Type B; 4 patients & \\
\hline & Type C; 5 patients & Type C; 5 patients & \\
\hline & Type D; 3 patients & Type D; 3 patients & \\
\hline \multicolumn{4}{|c|}{ Medial sensitivity with palpation, VAS Score } \\
\hline $\mathrm{I}^{\text {st }}$ year & $2.9 \pm 2.34(0-5)$ & $3.04 \pm 2.94(0-6)$ & $.875^{¥}$ \\
\hline $2^{\text {nd }}$ year & $2.64 \pm 2.12(0-5)$ & $2.84 \pm 2.85(0-5)$ & $.774^{¥}$ \\
\hline Union time (mo) & $2.23 \pm 0.56(1.8-2.9)$ & $2.46 \pm 0.45(1.9-3.1)$ & $.475^{¥}$ \\
\hline Follow-up time (mo) & $31.45 \pm 8.16(28-44)$ & $26.5 \pm 4.45(25-29)$ & \\
\hline \multicolumn{4}{|l|}{ AOFAS scale } \\
\hline Mean \pm SD $\left(2^{\text {th }} \mathrm{mo}\right)$ & $60.40 \pm 7.78(46-79)$ & $73.60 \pm 10.80(53-87)$ & $<.001^{\pi}$ \\
\hline Mean $\pm S D\left(6^{\text {th }} \mathrm{mo}\right)$ & $88.93 \pm 4.11(84-97)$ & $90.8 \pm 4.96(84-97)$ & $0.27^{\pi}$ \\
\hline Mean $\pm S D\left(12^{\text {th }} \mathrm{mo}\right)$ & $95.40 \pm 4.70(90-100)$ & $98.07 \pm 3.49(90-100)$ & $0.089^{\pi}$ \\
\hline Mean $\pm S D\left(24^{\text {th }} \mathrm{mo}\right)$ & $94.90 \pm 3.87(90-100)$ & $97.17 \pm 4.67(90-100)$ & $0.082^{\pi}$ \\
\hline Removal of implants (mo) & 3 patients $(8,14,16)$ & 4 patients $(13,14,16,18)$ & \\
\hline
\end{tabular}

${ }^{¥}$ Fisher's exact test. "Independent t-samples test. AOFAS: American foot and ankle society; SD: Standard deviation; VAS: Visual Analog Scale.

The mean AOFAS Ankle-Hindfoot Score at 2 months postoperatively was 60.40 77.78 (range, 46-79) in Group A and $73.60 \pm 10.80$ (range, 53-87) in Group B, indicating a statistically significant difference between the groups $(p<0.0 I)$. However, there was no statistically significant difference in the mean AOFAS scores between Group A and Group B at 6 months postoperatively $(88.93 \pm 4$. II vs. $90.8 \pm 4.96$, respectively; $p=0.27)$. In addition, the mean AOFAS scores were comparable at 12 months $(95.40 \pm 4.70$ vs. $98.07 \pm 3.49$, respectively; $p=0.089)$ and 24 months $(94.90 \pm 3.87$ vs. $97.17 \pm 4.67$, respectively; $p=0.082$ ) postoperatively between the groups.

The mean VAS pain scores at 12 months postoperatively were 2.9 2.34 (range, 0-5) in Group A and 3.04 \pm 2.94 (range, $0-6)$ in Group B, indicating no statistically significant difference between the groups $(p>0.05)$. The mean VAS pain scores at 24 months postoperatively were 2.64 2.12 (range, 0-5) in Group A and 2.84 \pm 2.85 (range, 0-5) in Group B, indicating no statistically significant difference between the groups $(p>0.05)$.

\section{DISCUSSION}

In daily practice, isolated medial malleolar fractures are treated surgically to ensure joint integrity and to prevent non-union and post-traumatic arthritis. However, there are studies showing that isolated medial malleolar fractures can also be conservatively treated. ${ }^{[1,7]}$ In a randomized-controlled study by Hoelsbrekken et al.," ${ }^{[7]}$ favorable outcomes were achieved through the conservative treatment of medial malleolar fractures with a displacement of $<2 \mathrm{~mm}$. Permanent displacement causes talar tilt by impairing the ankle biomechanics, thereby, leading to the development of post-traumatic arthritis. In our clinical practice, we treat cases with a displacement of more than $2 \mathrm{~mm}$ using the surgical treatment option and included cases with pre-operative displacements of more than $2 \mathrm{~mm}$ in the present study. However, Herscovici et al. ${ }^{[1]}$ reported a successful union rate at mid-term followup in $\mathbf{5 7}$ cases treated for isolated medial malleolar fractures without considering the level of displacement, although they concluded that surgical treatment indications should be present for open fractures and bi-trimalleolar fractures. In their case series, the treatment was successful even with an average displacement of $4.7 \mathrm{~mm}$.

In a small-scale study by Tekin et al., ${ }^{[8]} 12$ patients who underwent fixation with antegrade headless screws were evaluated and successful outcomes were achieved without nonunion, instability, or additional problems, with a mean AOFAS 
score of $95.0 \pm 5.4$. In another study investigating the clinical and radiological results of surgically treated isolated medial malleolar fractures, Bulut and Gursoy ${ }^{[9]}$ reported that fixation with headless screws resulted in significantly less pain in the medial malleolar area than with cannulated cancellous screws or TBW fixation, while there was no significant difference in the clinical outcomes $(p=0.239)$. The authors also found a mean VAS pain score of $0.09 \pm 0.3$ for fixation with headless screws, and there was a significant difference in the VAS pain scores on the medial malleolar between fixation with headless screws and fixation with TBW $(p=0.003)$. In the present study, the mean VAS pain score at 12-24 months was 2.9 \pm 2.34 and 2.64 \pm 2 .12, respectively, in Group $A$ and $3.04 \pm 2.94$ and $2.84 \pm 2.85$, respectively, in Group B. These findings indicate that fixation with headless screws results in less tenderness at the medial malleolus. No early (at 2-6 months postoperatively) clinical follow-up was reported in the aforementioned studies. ${ }^{[8,9]}$ Despite the very good clinical outcomes in these studies and in our study, there is still a lack of biomechanical evidence in the literature.

Several techniques have been described for the surgical fixation of medial malleolar fractures, among which the most commonly used techniques are compression with TBW and cancellous lag screws. ${ }^{[10-15]}$ On the other hand, although it usually depends on the type of fracture, techniques can be superior to each other. In cases where the distal medial malleolar fragment is small, the treatment with TBW is safer, as cannulated cancellous screws may break the distal screws. Likewise, vertical countersunk 4-mm lag screws used in low transverse fractures or for plate fixation in high horizontal fractures may be safer in surgical terms. ${ }^{[4,16,17]}$

In the present study, the outcomes were more satisfactory at the early post-operative $2^{\text {nd }}$ month in the cases treated with a cannulated cancellous screw and an additional miniplate than in those treated with only a cannulated cancellous screw and K-wire for fixation. The mean AOFAS score was $60.40 \pm 7.78$ in the group treated with only a cannulated cancellous screw and $\mathrm{K}$-wire, compared to $73.60 \pm 10.80$ in the group stabilized with a miniplate in addition to the cannulated cancellous screw and K-wire. The results were statistically significant in favor of the group treated with the additional miniplate $(p<0.05)$. Early stabilization of the fracture line with a miniplate probably provided more stable fixation, resulting in much better clinical scores. However, when the mean AOFAS scores were examined at 6,12 , and 24 months post-operatively, there was no significant difference between the two techniques in the mid-term and none of the patients developed ankle instability, post-traumatic arthritis, or metal failure during follow-up. These results suggest that isolated medial malleolar fractures can be surgically treated successfully. We believe that the lack of intra-articular step-off, good reduction, and secondary stable fixation are the main determinants of returning to daily living activities after the treatment of medial malleolar fractures. Furthermore, there are studies in the literature com- paring implants related to tibial fractures and investigating the effects of implant designs in fracture healing. ${ }^{[18]}$ In the present study, early AOFAS clinical scores appeared to be significantly higher. For patients treated with a cannulated cancellous screw, K-wire, and mini-plates, our leading concerns following surgery were the development of irritation, necrosis, and skin pathologies at the implant site where the miniplate was applied due to the thinness of the subcutaneous tissue and skin in the medial malleolus region; however, none of the patients experienced such complications in our study. Even the patients who described pain in that area on palpation experienced no adverse effect in their daily life.

Nonetheless, there are some limitations to this study. First, the study has a single-center and retrospective design with a relatively small sample size which precludes the generalizability of these findings. Second, there is a lack of comparison of the clinical scores with those of conservatively treated cases, although this is an issue with ethical concerns. Third, we were unable to compare biomechanics of the two methods.

\section{Conclusion}

The treatment of medial malleolar fractures with a cannulated cancellous screw and $\mathrm{K}$-wire with additional stabilization using a miniplate ensures favorable early outcomes with early return to daily living activities. However, both techniques have similar outcomes in the mid-term. We believe that this technique would be a guide in the treatment of future patients. However, further large-scale, long-term, prospective, and randomized-controlled studies are needed to draw a firm conclusion on this subject.

Ethics Committee Approval: This study was approved by the Nigde Omer Halisdemir University Ethics Committee (Date: 24.I 2.2020, Decision No: 2020/67).

Peer-review: Internally peer-reviewed.

Authorship Contributions: Concept: M.A., S.Ç.; Design: M.A., S.Ç.; Supervision: M.A., S.Ç.; Resource: M.A., S.Ç.; Materials: M.A., S.Ç.; Data: M.A., S.Ç.; Analysis: M.A., S.Ç.; Literature search: M.A., S.Ç.; Writing: M.A., S.Ç.; Critical revision: M.A., S.Ç.

Conflict of Interest: None declared.

Financial Disclosure: The authors declared that this study has received no financial support.

\section{REFERENCES}

1. Herscovici D Jr., Scaduto JM, Infante A. Conservative treatment of isolated fractures of the medial malleolus. J Bone Joint Surg 2007;89B:89.

2. Joy G, Patzakis MJ, Harvey JP. Precise evaluation of the reduction of severe ankle fractures: Technique and correlation with end results. J Bone Joint Surg 1974;56-A:979-93. [CrossRef]

3. Müller ME, Nazarian S, Koch P, Schatzker J. The Comprehensive Classification of Fractures of Long Bones. Berlin: Springer-Verlag; 1988. p. 180-91. 
4. Canale T, Beaty JH. Campbell Orthopedics Textbook. 12th ed. Elsevier Mosby, 2008. p. 2619-30.

5. Pankovich AM, Shivaram MS. Anatomical basis of variability in injuries of the medial malleolus and the deltoid ligament. I: Anatomical studies. Acta Orthop Scand 1979;50:217-23. [CrossRef]

6. Kitaoka HB, Alexander IJ, Adelaar RS, Nunley JA, Myerson MS, Sanders M. Clinical rating systems for the ankle-hindfoot, midfoot, hallux, and lesser toes. Foot Ankle Int 1994;15:349-53. [CrossRef]

7. Hoelsbrekken SE, Kaul-Jensen K, Mørch T, Vika H, Clementsen T, et al. Nonoperative treatment of the medial malleolus in bimalleolar and trimalleolar ankle fractures: A randomized controlled trial. J Orthop Trauma 2013;27:633-7. [CrossRef]

8. Tekin AC, Çabuk H, Dedeoglu SS, Saygı1ı MS, Adaş M, Büyükkurt CD, et al. Anterograde headless cannulated screw fixation in the treatment of medial malleolar fractures: Evaluation of a new technique and its outcomes. Med Princ Pract 2016;25:429-34. [CrossRef]

9. Bulut T, Gursoy M. Isolated medial malleolus fractures: Conventional techniques versus headless compression screw fixation.J Foot Ankle Surg 2018;57:552-6. [CrossRef]

10. Jennings MM, Schuberth JM. Fixation of the medial malleolar fracture: A simplified technique. J Foot Ankle Surg 2008;47:368-71. [CrossRef]

11. Koslowsky TC, Mader K, Kirchner S, Gausepohl T, Pennig D. Treatment of medial malleolar fractures using fine-threaded $\mathrm{K}$-wires: A newo- perative technique. J Trauma 2007;62:258-61. [CrossRef]

12. Kupcha P, Pappas S. Medial malleolar fixation with a bicortical screw: Technique tip. Foot Ankle Int 2008;29:1151-3. [CrossRef]

13. Maniar H, Kempegowda H, Tawari AA, Rutter MR, Borade A, Cush G, et al. Medial malleoli fractures: Clinical comparison between newly designed sled device and conventional screws. Foot Ankle Spec 2017;10:296-301. [CrossRef]

14. Pollard JD, Deyhim A, Rigby RB, Dau N, King C, Fallat LM, et al. Comparison of pullout strength between $3.5-\mathrm{mm}$ fully threaded, bicortical screws and $4.0-\mathrm{mm}$ partially threaded, cancellous screws in the fixation of medial malleolar fractures. J Foot Ankle Surg 2010;49:248-52. [CrossRef]

15. Rovinsky D, Haskell A, Liu Q, Paiement GD, Robinovitch S. Evaluation of a new method of small fragment fixation in a medial malleolus fracture model. J Orthop Trauma 2000;14:420-5. [CrossRef]

16. Georgiadis GM, White DB. Modified tension band wiring of medial malleolar ankle fractures. Foot Ankle Int 1995;16:64-8. [CrossRef]

17. Johnson BA, Fallat LM. Comparison of tension band wire and cancellous bone screw fixation for medial malleolar fractures. J Foot Ankle Surg 1997;36:284-9. [CrossRef]

18. Tekin SB, Mert A, Bozgeyik B. Which is superior in the treatment of AO Type 42A tibial shaft fracture? A comparison of talon intramedullary nailing and conventional locked intramedullary nailing. Ulus Travma Acil Cerrahi Derg. 2022. doi: 10.14744/tjtes.2021.36779. [[Ahead of Print]

\section{ORIJINAL ÇALIŞMA - ÖZ}

Geleneksel bir tekniğin gelişimi: Medial malleol kırıklarının tedavisinde 4 mm'lik kanüllü vida ve Kirschner teli tekniği ile 4 mm’lik kanüllü vida, Kirschner teli tekniği ve kayma önleyici mini plak tespitinin karşılaştırılması

\section{Dr. Murat Aydın, ${ }^{1}$ Dr. Selim Çinaroğlu²}

${ }^{1}$ Niğde Ömer Halisdemir Üniversitesi Tıp Fakültesi, Ortopedi ve Travmatoloji Anabilim Dalı, Niğde

${ }^{2}$ Niğde Ömer Halisdemir Üniversitesi Tıp Fakültesi, Anatomi Anabilim Dalı, Niğde

AMAÇ: Cerrahi tedavi yapılan izole medial malleol kırılarında kanüllü vida, Kirschner teli fiksasyonu ile beraber mini plak vida kombinasyonunu değerlendirmektir.

GEREÇ VE YÖNTEM: A grubunda medial malleol kırı̆̆ $4 \mathrm{~mm}$ kanülle vida ve Kirschner teli ile fikse edilmiş grup, B grubunda ise medial malleol kırığı $4 \mathrm{~mm}$ kanüllü vida ve Kirschner teli ile fikse edilen ve ekstra stabilite için mini plak ile fiksasyon yapılan gruptur. AOFAS skorlaması ameliyat sonrası 2, 6 ve I2. ayda alınan skorlar göz önüne alındı. Medial malleol üzerinde palpasyonla hassasiyet ameliyat sonrası I2. ayda VAS of pain skalası ile değerlendirildi.

BULGULAR: İndependent t samples teste göre A ve B grubu arasında istatistiksel anlamlı bir fark vardır $(p<0.05)$. Ameliyat sonrası altıncı ayda A grubu ile B grubu arasında independent t samples teste göre istatistiksel olarak anlamlı fark yoktur ( $p=0.27$ ). Ameliyat sonrası 6,12 ve 24 . ayda $A$ grubu ile B grubu arasında independent t samples teste göre istatistiksel olarak anlamlı fark yoktur. İki grup arasında VAS of pain skorunda Fisher's exact testine göre istatisksel olarak anlamlı fark bulunamadı.

TARTIŞMA: Medial malleol kırıklarında kanulle vida, K-teli ile primer tespit edilen miniplak ile ek stabilte sağlanan olgularda erken dönem sonuçları ve erken dönemde günlük hayata dönüş sadece kanülle vida ve K-teli yapılan olgulara göre daha iyi ve hızlıdır. Orta dönemde iki teknik arasında anlamlı bir fark yoktur

Anahtar sözcükler: Açık redüksiyon internal fiksasyon; K-teli; medial malleol kırıkları; miniplak; travma.

Ulus Travma Acil Cerrahi Derg 2022;28(3):336-343 doi: 10.14744/tjtes.2021.49734 